\title{
PELATIHAN PEMANFAATAN LIMBAH RAMBUT JAGUNG (Zea maysL.) SEBAGAI TEH ANTIDIABETIK DAN ALTERNATIF WIRAUSAHA (Studi Di Dusun Cung Belut, Desa Semen, Kecamatan Paron, Kabupaten Ngawi )
}

\author{
Training Using Corn Hair Waste (Zea Maysl.) As An Antidiabetic Tea And Alternative \\ Entrepreneurs (Study in Cung Belut Hamlet, Semen Village, Paron District, \\ Ngawi Regency)
}

\author{
Nurul Hidayah ${ }^{1}$ \\ ${ }^{1}$ Akademi Keperawatan Pemerintah Kabupaten Ngawi; Jl. Dr. Wahidin No 49 Ngawi \\ 63212 Telp. (0351) 744859, email: nurulridlo@ gmail.com
}

\begin{abstract}
ABSTRAK
Latar belakang: Dusun Cung Belut merupakan salah satu dusun agraris dengan komoditas utamanya jagung. Selama ini masyarakat hanya mengetahui manfaat dari buah jagung, sedangkan rambut jagung masih dianggap limbah yang tidak dimanfaatkan. Melihat potensi alam dan sumber daya manusia yang dimiliki, perlu dilakukan peberdayaan untuk meningkatkan kesejahteraan masyarakat dengan berpijak pada potensi yang dimiliki wilayah ini. Tujuan: Memberikan keterampilan warga tentang cara pengolahan limbah rambut jagung menjadi teh antidiabetik pada penderita DM dan sebagai alternatif wirausaha Populasi: Warga Dusun Cung Belut yang menderita DM dan kelompok risiko DM sebanyak 50 orang. Metode: Penyuluhan kesehatan, demonstrasi pemberian ketrampilan tentang pembuatan teh rambut jagung, dan pemeriksaan kesehatan. Waktu: Kegiatan dilaksanakan antara 1 Februari-1 Maret 2019. Hasil: Pengetahuan warga tentang cara pengolahan limbah rambut jagung menjadi teh antidiabetik pada penderita DM meningkat sebesar $85 \%$, dan $70 \%$ partisipan menyatakan berminat untuk berwirausaha teh rambut jagung. Hasil pemeriksaan kadar gula darah dalam kategori normal sebanyak 14 partisipan, dan hiperglikemi sebanyak 36 partisipan. Pemeriksaan IMT kategori normal sebanyak 12 partisipan, kurang 6 partisipan, berlebih 23 partisipan dan obesitas 9 partisipan. Kesimpulan kegiatan pengabdian ini efektif meningkatkan pemahaman warga tentang pemanfaatan limbah rambut jagung sebagai teh antidiabetik dan alternatif wirausaha.
\end{abstract}

Kata Kunci: teh rambut jagung, antidiabetik, wirausaha

\begin{abstract}
Background: Cung Belut Hamlet is one of the agrarian hamlets with its main commodities being corn. So far, the community only knows the benefits of corn fruit, while corn hair is still considered a waste that is not utilized. Seeing the natural potential and human resources that are owned, it needs to be empowered to improve the welfare of the community by resting on the potential possessed by this region. Objective: To provide skills for residents on how to process corn hair waste into antidiabetic tea in DM patients and as an entrepreneurial alternative Population: Cung Belut Hamlet residents who suffer from DM and DM risk groups as many as 50 people. Methods: Health education, demonstration of giving skills about making corn hair tea, and health checks. Time: Activities carried out between 1 February and 1 March 2019. Results: Citizens' knowledge of how to process corn hair waste into antidiabetic tea in DM patients increased by $85 \%$, and $70 \%$ of participants expressed interest in entrepreneurship corn hair tea. The results of examination of blood sugar levels in the normal category were 14 participants, and hyperglycemia as many as 36 participants. Normal category BMI examination was 12 participants, less than 6 participants, over 23 participants and obese 9 participants. The conclusion of this service activity was to effectively increase people's understanding of the utilization of corn hair waste as an antidiabetic tea and an entrepreneurial alternative
\end{abstract}

Keywords: corn hair tea, antidiabetic, entrepreneurship 


\section{PENDAHULUAN}

Dusun Cung Belut merupakan salah satu Dusun yang terletak di Desa Semen Kecamatan Paron Kabupaten Ngawi Propinsi Jawa Timur. Luas Dusun ini sebesar 1.284.118 ha. Jumlah penduduk di Dusun ini sebesar 467 jiwa terdiri dari 232 pria dan 235 wanita. Dusun ini merupakan Dusun Agraris, dengan komoditas utama yang dihasilkan adalah Jagung. Tingkat pendidikan penduduk rata-rata adalah SD. Hal ini mengakibatkan sulitnya mencari pekerjaan yang lebih baik, sehingga berpampak pada tingkat pendapatan penduduk rata-rata sebesar Rp 500.000-Rp1.000.000/bulan. Hasil panen jagung tiap tahun mencapai 230 ton. Selama ini warga hanya memanfaatkan hasil panennya dari buah jagung saja, sedangkan untuk rambut jagung dianggap sabagai limbah yang biasanya dibuang sia-sia. Padahal dalam rambut jagung terdapat senyawa bioaktif seperti protein, vitamin, karbohidrat, garam-garam, kalsium, kalium, magnesium, natrium, minyak atsiri, steroid seperti sitosterol dan stigmasterol, alkaloid, saponin, tanin, dan flavonoid. Senyawa flavonoid berfungsi sebagai antioksidan yang berfungsi melindungi kerusakan sel-sel tubuh sebagai akibat paparan dari radikal bebas (Guo, 2009). Sumber antioksidan alami banyak dijumpai pada buah dan sayu-sayuran, dan telah terbukti melindungi sel-sel tubuh dari kerusakan oksidatif (Kurniasih, 2013). Proses pengeringan rambut jagung akan mempengaruhi kadar antioksidan yang terkandung didalamnya. Menurut penelitian Putri (2016) kadar antioksidan tertinggi pada rambut jagung diperoleh dengan cara dikeringkan pada suhu $50^{\circ} \mathrm{c}$ sebesar $85,8 \%$, hal berbeda dikatakan oleh Ismiati (2015), bahwa aktivitas antioksidan rambut jagung tertinggi didapatkan pada rambut jagung segar dibandingkan dengan yang dikeringkan, dengan lama perebusan kurang lebih 5 menit sebesar 59,404\%. Kandungan flavonoid dalam $100 \mathrm{~g}$ rambut jagung kering sebesar 219 gr (Hidayah \& Nisak, 2018) Rambut jagung juga berpotensi menurunkan kadar gula darah pada tikus putih jantan galur wistar (Rattus norvegicus L.) yang diinduksi aloksan sebesar 130 $\mathrm{mg} / \mathrm{KgBB}$ secara intraperitoneal, dengan efektivitas dosis sesesar 2,52 $\mathrm{g} / \mathrm{KgBB}$ yang diminum selama 14 hari berturut-turut (Koloay et al., 2015). Penelitian Hidayah \& Nisak (2018) mengatakan teh rambut jagung terbukti menurunkan kadar gula darah penderita DM tipe 2 setelah dikonsumsi berturutturut selama 14 hari.

Melihat potensi alam dan potensi sumber daya manusia yang dimiliki oleh Dusun Cung Belut, maka perlu dilakukan suatu kegiatan untuk meningkatkan kesejahteraan masyarakat di wilayah tersebut. Pemberdayaan masyarakat yang dilakukan berpijak dari potensi yang dimiliki oleh wilayah ini, antara lain dari hasil pertanian seperti jagung. Oleh karena itu, kegiatan pengabdian masyarakat ini diarahkan pada pemberdayaan masyarakat melalui pelatihan pemanfaatan limbah rambut jagung (Zea maysL.) sebagai teh antidoabetik dan alternatif wirausaha menggunakan bahan dasar jagung yang mudah diperolah dari wilayah tersebut. Teknologi olahan bahan pangan yang akan diprogramkan antara lain: pembuatan teh rambut jagung. Teh rambut jagung ini sangat berpotensi untuk dikembangkan menjadi produk wirausaha karena peluang pasarnya yang cukup menjanjikan, salah satunya sebagai terapi komplementer pada 
pasien DM tipe 2. Selain pelatihan berupa keterampilan pembuatan teh rambut jagung, akan diberikan pula penyuluhan tentang kewirausahaan, penyuluhan penyakit seputar DM, dan pemeriksaan kesehatan tentang kadar gula darah dan IMT. Dengan demikian, melalui program pengabdian ini diharapkan dapat meningkatkan kesejahteraan masyarakat di Cung Belut Desa Semen Kecamatan Paron Kabupaten Ngawi. Kegiatan pengabdian ini sekaligus akan mendukung arah kebijakan pembangunan Kabupaten Ngawi, yaitu :(1) Menanggulangi kemiskinan secara terpadu dan berkelanjutan . Mengembangkan iklim usaha dan ekonomi kerakyatan berbasis agraris (Pemda Ngawi, 2019). Berdasarkan uraian latar belakang diatas, penulis tertarik melakukan kegiatan pengabdian masyarakat yang berjudul "Pelatihan Pemanfaatan Limbah Rambut Jagung (Zea maysL.) Sebagai Teh Antidiabetik Dan Alternatif Wirausaha Di Dusun Cung Belut Desa Semen Kecamatan Paron Kabupaten Ngawi"

TUJUAN: Memberikan keterampilan warga tentang cara pengolahan limbah rambut jagung menjadi teh antidiabetik dan sebagai alternatif wirausaha

METODE Kegiatan pengabdian menggunakan metode penyuluhan kesehatan, demonstrasi pemberian ketrampilan tentang pembuatan teh rambut jagung, dan pemeriksaan kesehatan kepada warga Dusun Cung Belut. Tahapan pelaksanaan pengabdian meliputi tahap persiapan, pelaksanaan dan evaluasi kegiatan. Tahap persiapan kegiatan ini meliputi: pengurusan surat izin pengabdian dari Institusi AKPER PemKab Ngawi ke Kesbangpol, dan Desa. Pada tahap ini juga dilakukan survey awal untuk pencarian data dasar demografi, karakteristik partisipan dan data seputar permasalahan kesehatan yang terdapat di dusun Cung Belut. Untuk memperlancar kegiatan survey awal, penulis bekerjasama dengan Kepala Desa, Kepala Dusun, RT, RW, dan para Tokoh masyarakat terkait dibantu dengan mahasiswa AKPER.

Kegiatan ini berlangsung pada tanggal 2 Februari - 5 Februari 2019 Pada tahap pelaksanaan dilakukan kegiatan pemeriksaan kesehatan, penyuluhan dan demonstrasi pembuatan teh rambut jagung. Tahap evaluasi kegiatan dilakukan pengkuran tingkat pemahaman partisipan melalui kuesioner yang dibagikan diakhir penyuluhan.

\section{POPULASI}

Target populasinya adalah warga Dusun Cung Belut Kecamatan Paron yang menderita DM dan kelompok risiko DM sebanyak 50 orang.

\section{WAKTU PELAKSANAAN}

Kegiatan dilaksanakan mulai tanggal 1 Februari sampai dengan 1 Maret 2019 di Dusun Cung Belut Desa Semen Kecamatan Paron Kabupaten Ngawi.

\section{HASIL DAN PEMBAHASAN Data demografi}

Jumlah penduduk Dusun Cung Belut pada tahun 2019 adalah: 467 jiwa, dengan penduduk laki-laki sebesar 232 jiwa, perempuan 235 jiwa. Distribusi penduduk berdasarkan kelompok usia: Balita 35 orang, Anak 56 orang, Remaja 68 orang, Dewasa 225 orang, dan Lansia 83 orang. Terdapat $158 \mathrm{KK}$ dan 142 somah.

\section{Pekerjaan Dan Pendapatan}

Sebagian warga bekerja sebagai petani sebanyak 179 orang, IRT 40, Karyawan swasta2, Pedagang 17, PNS 1, Buruh tani 18, Pensiun 1, Pengangguran 12, 
dengan pendapatan rata-rata $\mathrm{Rp}$

500.000-Rp1.000.000/ bulan

\section{Kegiatan penyuluhan tentang penyakit Diabetes dan pemanfaatan limbah rabut jagung sebagai antidiabetik}

Tujuan dari kegiatan penyuluhan ini adalah meningkatkan pengetahuan warga tentang manfaat teh rambut jagung sebagai terapi komplementer pada penyakit Diabetes. Persiapan kegiatan ini meliputi: koordinasi dengan perangkat desa seperti kepala desa, kepala Dusun, ketua RT, RW dan kader untuk mensosialisasikan kegiatan penyuluhan yang akan dilakukan pada tanggal 15 Februari 2019. Tema dari penyuluhan ini adalah "Sosialisasi pemanfaatan teh rambut jagung sebagai terapi komplementer penderita DM Tipe2". Materi yang diberikan meliputi penyakit DM, dan penanganannya menggunakan terapi komplementer khususnya teh rambut jagung. Kegiatan penyuluhan materi ini berlangsung selama 60 menit. Jumlah warga yang diundang 50 orang. Kegiatan ini mendapat dukungan dari warga dan perangkat desa, hal ini dapat dilihat dari jumlah undangan yang hadir dan antusias warga bertanya seputar penyakit DM dan manfaat Teh Rambut Jagung. Dukungan lain dari warga juga diperlihatkan dari cara warga datang lebih awal pada pelaksanaan penyuluhan. Warga bersama mahasiswa juga membantu menyiapkan tempat berkumpul untuk acara penyuluhan, meminjamkan sarana prasarana seperti rumah untuk pertemuan, tikar, mic, sound, dan membantu kebutuhan konsumsi kegiatan.

- Evaluasi dari kegiatan ini adalah peningkatan pemahaman warga tentang manfaat teh rambut jagung sebagai teh antidiabetik pada penyakit DM sebesar $85 \%$

\section{Demonstrasi cara memproduksi teh tambut jagung}

Kegiatan penyuluhan ini

dilakukan pada tanggal 15 Februai 2019, dengan tujuan meningkatkan pemahaman warga tentang cara membuat teh rambut jagung untuk tujuan konsumsi sendiri ataupun untuk dijual. Pada kegiatan ini diberikan materi tentang tentang cara memproduksi teh rambut jagung mulai dari cara mendapatkan bahan baku rambut jagung, cara membersihkan rambut jagung dari kotoran, cara pengeringan rambut jagung hingga siap dikemas, cara penimbangan dan pengemasan teh rambut jagung. Selain itu juga diajarkan analisis usaha untuk produksi teh rambut jagung meliputi besarnya modal yang diperlukan dan analisis profit yang diperoleh dari setiap $\mathrm{kg}$ pembelian bahan baku rambut jagung sampai menjadi teh siap konsumsi. Pada kegiatan ini juga diajarkan tentang prospek usaha teh rambut jagung yang sangat potensial untuk dikembangkan, mengingat wilayah Dusun Cung Belut merupakan penghasil jagung. Diakhir penyuluhan tak lupa penulis memberikan materi tentang bagaimana cara memulai usaha teh rambut jagung dan memotivasi warga untuk memulai usaha teh rambut jagung.

Evaluasi kegiatan dilakukan dengan pemberikan angket yang menjadi tolak ukur motivasi peserta pelatihan untuk memulai usaha secara mandiri dengan keterampilan yang telah diberikan. Indikator keberhasilan dari kegiatan ini adalah bila lebih dari 50\% partisipan termotivasi untuk membuka wirausaha melalui keterampilan ini. Melalui pelatihan pembuatan ini $70 \%$ partisipan termotivasi untuk membuat teh rambut jagung minimal untuk konsumsi sendiri 


\section{Pemeriksan Kesehatan}

Pemeriksaan kesehatan yang dilakukan meliputi pemeriksaan kadar gula darah sewaktu dan penilaian status gizi (BB, TB, IMT) partisipan. Hal ini dilakukan karena sebagian besar partisipan yang diundang dalam kegiatan ini adalah penderita DM Tipe 2 dan kelompokkelompok risiko DM. Pemeriksaan kesehatan juga dimaksudkan untuk menarik minat partisipan datang ke acara penyuluhan. Pemeriksaan ini dilakukan sesaat setelah partisipan tiba di lokasi pengabdian.

Dari hasil pemeriksaan kadar gula darah partisipan dalam kategori normal sebanyak 14 partisipan, dan hiperglikemi sebanyak 36 partisipan. Pemeriksaan IMT kategori normal sebanyak 12 partisipan, kurang 6 partisipan, berlebih 23 partisipan dan obesitas 9 partisipan.

\section{KESIMPULAN}

Kegiatan pengabdian masyarakat yang dilakukan dengan modifikasi teknik penyuluhan, demontrasi, dan pemeriksaan kesehatan terbukti efektif untuk meningkatkan pemahaman warga tentang pemanfaatan limbah rambut jagung (Zea Maysl.) sebagai teh antidiabetik dan alternatif wirausaha pada masyarakat Dusun Cung Belut

\section{SARAN}

1. Kegiatan ini perlu dikembangkan lebih lanjut untuk merealisasikan wirausaha pembuatan teh rambut jagung mengingat potensi bahan baku yang melimpah dan sumber daya yang memadai.

2. Diperlukan peran serta Pemerintah Daerah dan instansi terkaitan untuk mengembangkan usaha kecil menengah di bidang ini.

\section{UCAPAN TERIMAKASIH}

Ucapan terimakasih disampaikan kepada Akper PemKab Ngawi, yang telah mendanai kegiatan Pengabdian masyarakat ini. Penulis juga mengucapkan terimakasih kepada Kepala Desa Semen, kepala dusun Cung Belut, ibu-ibu kader dan warga Desa Semen yang telah membantu kegiatan terlaksananya program pengabdian masyarakat.

\section{DAFTAR PUSTAKA}

Guo, J., Liu, T., Han, L. \& Liu, Y. 2009. The Effects of Corn Silk on Glycaemic Metabolism. Nutrition \& Metabolism. 6:47.

Hidayah, N., Nisak, R., 2018, Buku ajar terapi komplementer untuk mahasiswa keperawatan: Evidence Based Practice. Yogyakarta: Samudra Biru

Hidayah, N., Nisak, R., 2018. The effect of corn silk tea on blood glucose level in patients with type 2 diabetes mellitus, International conference on public health. DOI: https://doi.org/10.26911/theicp h.2018.05.17 Tersedia dalam: http://theicph.com/id_ID/2018/09/12/ the-effect-of-corn-silk-tea-on-bloodglucose-level-in-patients-with-type2-diabetes-mellitus/

Ismiati, E.R. 2015 Aktivitas antioksidan minuman herbal rambut jagung dengan varian kondisi dan lama perebusan, Skripsi, Universita Muhammadiyah Surakarta

Kolay, K., Citraningtyas,G., Lolo,W.A., 2015. Uji efektivitas ekstrak etanol rambut jagung (Zea mays L) Terhadap penurunan kadar gula darah tikus putih jantan wistar (ratus norvegicus L) yang diinduksi aloksan, Manado. Jurnal ilmiah farmasi: vol 4 (3) ISSN 2302 - 2493

Kurniasih.2013. Khasiat dan manfaat daun kelor untuk penyembuhan 
berbagai penyakit. Yogyakarta : Pustaka baru Press.

Pemda Ngawi, 2019.Visi dan misi pemerintah kabupaten ngawi periode $2016 \quad-\quad 2021$ https://ngawikab.go.id/visi-dan-misi/
Putri,F.K. 2016. Aktivitas antioksidan dan kualitas teh kombinasi rambut jagung dan daun kelor dengan variasi sugu pengeringan, Skripsi, Universitas Muhammadiyah Surakarta. 